Original Research

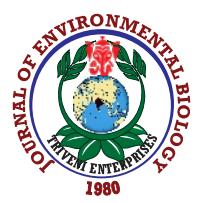

DOI : http://doi.org/10.22438/jeb/41/6/SI-260

\title{
Long term cultivation effects on nitrogen dynamics in polyhouse and open field vegetable growing soils of North-Western Himalayas
}

\author{
Shabnam* and S.K. Sharma \\ Department of Soil Science, Chaudhary Sarwan Kumar Himachal Pradesh Krishi Vishvavidyalaya, Palampur-176 062, India \\ *Corresponding Author Email : mehtashabnam05@gmail.com
}

\section{Abstract}

Aim: The present study was undertaken to assess the differences in the transformations of native nutrients between protected and open field conditions, affecting their availability to plants.

Methodology: The geo-referenced soil samples were collected from farmers' field growing vegetables under polyhouse and adjacent open fields for last 5 to 6 years. Collected soil samples were analysed for organic and inorganic pools of nitrogen. Means of the different land use types were compared by using Tukey HSD Procedure.

Results: Hydrolysable $\mathrm{NH}_{4}-\mathrm{N}$ was found as second most dominant form of nitrogen after amino acid-N, both under conventional and protected cultivation. In general, an increase was observed in hydrolysable $\mathrm{NH}_{4}-\mathrm{N}$ both under protected and conventional cultivation with respect to their fallow plots

Interpretation: Various fractions of nitrogen were found to be affected by the management practices and consequently status of nitrogen fractions was observed higher under polyhouse soil. Soil nutrient release under protected environment as compared to open field is necessary to observe the changes and adverse effect with ages of intensive cultivation under protected conditions.

Key words: Nitrogen pools, Polyhouse, Vegetables

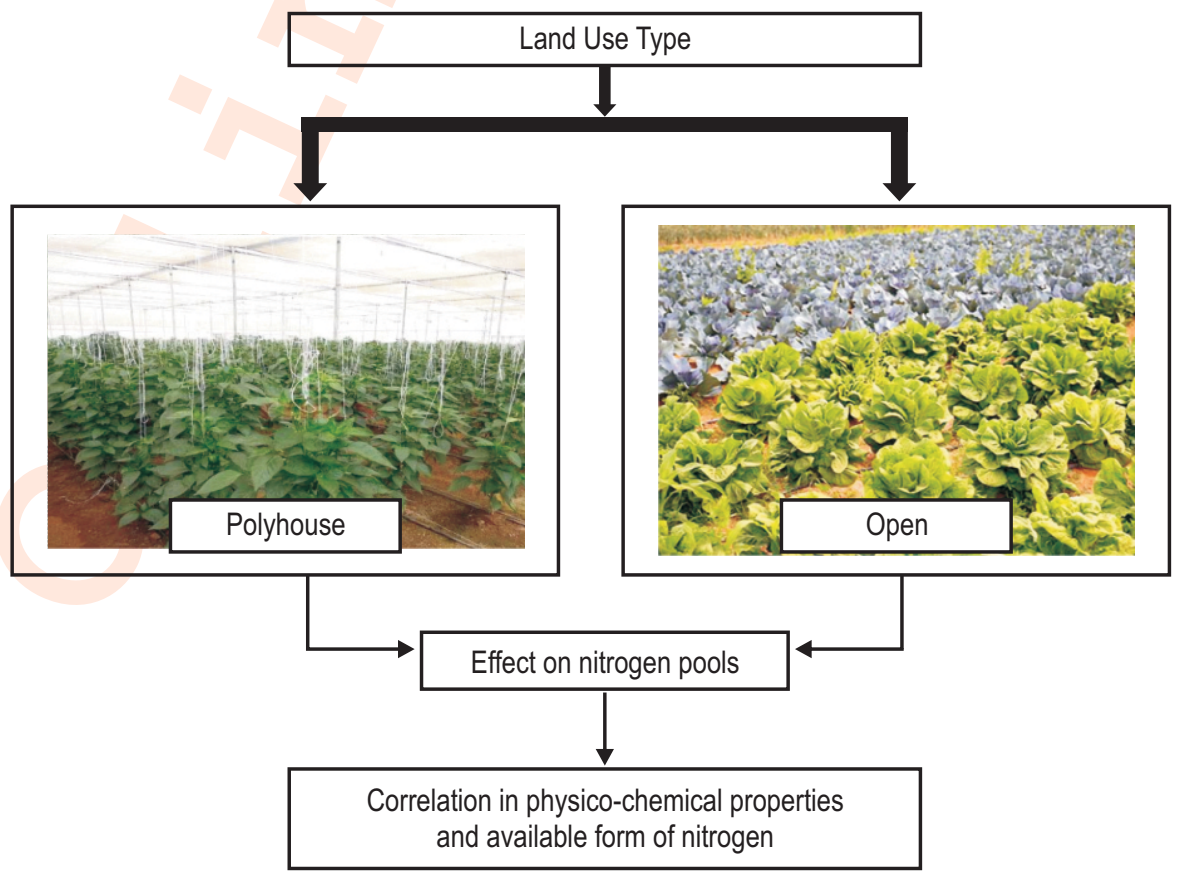

How to cite : Shabnam and S.K. Sharma: Long term cultivation effects on nitrogen dynamics in polyhouse and open field vegetable growing soils of North-Western Himalayas. J. Environ. Biol., 41, 1719-1723 (2020). 


\section{Introduction}

Productivity and sustainability of any production system not only depend upon the management practices, but also on the environment as well as on soil quality (Reynolds et al., 2009). It is well known fact that not only the available nutrients status of the soils' but also their chemical pools in which these nutrients occur, play an important role in the process of nutrient uptake and translocation. There is difference in utilization of native and added fertilizer nutrients but also in the extent of utilization from different chemical pools. Therefore, the present study was undertaken to assess the differences in the transformations of native nutrients between protected and open field conditions and the effect on their availability to plants. In vegetable production, India is the second largest producer of vegetables in the world, next to China. It produces 175 million tonnes of vegetables from 10.3 million ha area (NHB, 2016-17) which is, however, much less than the actual requirement for providing balanced diet to each individual. To cope up with the burgeoning population, the total production of vegetables in India needs to be raised to at least 250 million tonnes by $2024-25$. It means we have to increase the productivity vertically from the limited land resources as per capita land availability is decreasing day by day. In general, the farmers are still practicing less intensive and remunerative farming system under open field cultivation (Kokate et al., 2012). Besides, there are many constraints with respect to climatic conditions viz., moisture, temperature, sunshine hours, wind velocities, humidity and weather vagaries, coupled with nutrient deficiencies, excessive weed growth and insect pests attack leading to poor productivity. To overcome these constraints, "protected cultivation" a specialized high-tech cultivation system under polyhouse is being emphasized for last two decades. Protected vegetable cultivation has proved to be a good farming practice in various parts of different countries and has been developed rapidly during recent years because of comparatively higher economic benefits. In Himachal Pradesh too, protected vegetable cultivation has gained quite a good momentum particularly for vegetables and commercial crops due to higher productivity, intensive cropping and assured income. A large number of polyhouses has been constructed in the state occupying an area of about 223.2 ha (Chaudhary, 2016). However, intensive cultivation coupled with very high use of specific inputs under protected conditions may prove detrimental to soil health and produce quality in the long run due to over exploitation of native reserves of nutrients. As sustainability of intensive agriculture system is linked to maintenance of soil quality (Benbi and Saroa, 2012), it is well established fact that available nutrients status of soil is also a factor of the amount of soil nutrients in chemical forms accessible to plant roots or compounds likely to be convertible to such forms which are available to plants and play an important role in the process of nutrient uptake and translocation (Fageria and Baliger, 2005). Differences in the transformations of native as well as applied nutrients may exist between protected and open field conditions, affecting their availability to plants.

Therefore, in the present scenario of vegetable production under protected conditions in Himachal Pradesh, it becomes imperative to assess the impact of prevalent management practices with respect to use of fertilizers and other inputs on soil quality for sustained production. The changes in soil quality indicate, whether the management practices being adopted are sustainable or not.

\section{Materials and Methods}

Study area: The study was carried out in Kangra valley of Himachal Pradesh. It is situated in the Western Himalayas between $31^{\circ} 2^{\prime}$ to $32^{\circ} 5^{\prime} \mathrm{N}$ latitude and $75^{\circ}$ to $77^{\circ} 45^{\prime} \mathrm{E}$ longitude, surrounded by the Shivalik and Dhauladhar hills. Altitude varies between 650 to $1800 \mathrm{~m}$ above mean sea level. It has considerable diversity in its soils, physiography, land use patterns and cropping systems. The annual rainfall varies between 1500 to $3000 \mathrm{~mm}$. Soil of the study area are mostly ochrepts, well drained loamy to fine loamy soils. These soils are shallow black, brown and alluvial. Udalfs are also found (North-Eastern extremes of regions), which are high base unsaturated soils. Four main textural classes were observed i.e., sandy loam, sandy clay loam, loam and clay loam.

Criteria of selection, soil sampling, processing and analysis: Geo-referenced surface soil samples (0-0.15 m depth) were collected from 25 vegetables growing sites under protected (polyhouse) as well as conventional/open field conditions and a total of 100 samples were analysed. Soil samples (0-0.15 m depth) were collected each from polyhouse, open fields and fallows of open and polyhouse of selected sites at the end of each season. All the polyhouse selected for present study were naturally ventilated. Recommended doses of fertilizer as per the recommended package of practices 125:60:30, 200:200:200 and 350:350:350 of $\mathrm{N}: \mathrm{P}_{2} \mathrm{O}_{5}: \mathrm{K}_{2} \mathrm{O} \mathrm{kg}$ ha ${ }^{-1}$ for cabbage, capsicum, tomato and cucumber were applied, respectively. However, based on discussion with farmers and field observations, vast variation in nutrient management practices were observed in protected as well as conventional system of vegetable production. In the study area, farmers mainly used urea, 12:32:16 (IFFCO), 19:19:19 and 12:12:12 along with frequent additions of farm yard manure and vermicompost. Conventional system of vegetable production involved addition of urea along with FYM and vermicompost. Some farmers also used lime under protected system of vegetable production. The collected samples were air dried and processed in wooden pestle and mortar and then subsequently passed through a $2 \mathrm{~mm}$ sieve for the analyses of physico-chemical properties and chemical pools of nitrogen. Under physico-chemical properties, soil pH was determined by potentiometric method (Jackson, 1973). Electrical conductivity (EC) was also determined by potentiometric method by Jackson 
(1973) in 1:2 soil and water. However, organic carbon and cation exchange capacity (CEC) were determined by wet digestion and Neutral $1 \mathrm{~N}$ ammonium acetate extraction method (Walkley and Black, 1934) and (Piper, 1966), respectively, whereas, for organic pools of nitrogen, soil samples were used immediately after collection (fresh samples) for analysis. Organic and inorganic pools of nitrogen were determined using standard methods (Bremmer, 1965; Black, 1965), respectively.

Statistical analyses : The data expressed as mean $\pm S D$ and range from lowest to highest value observed under different sites. Means for different land use types were compared by using Tukey HSD Procedure (Steel and Torrie, 1960).

\section{Results and Discussion}

Soils of study area mainly varied from slightly acidic to acidic (Table 1). The soil pH ranged from 5.2 to 6.7 with mean of $5.9 \pm 0.42$ under protected area, whereas under open conditions, $\mathrm{pH}$ ranged between 5.2 to 6.3 with mean of $5.6 \pm 0.33$. There was wide variation in EC values of soil samples; however, all the samples both under protected and open system of cultivation were found within permissible limits for growing crops without salinity/alkalinity hazards. Organic carbon ranged from 6.4 to 11.7 $\mathrm{g} \mathrm{kg}^{-1}$, with mean of $8.1 \mathrm{~g} \mathrm{~kg}^{-1}$ under polyhouse soils; however, it ranged between 4.5 to $9.6 \mathrm{~g} \mathrm{~kg}^{-1}$ with mean of $7.0 \mathrm{~g} \mathrm{~kg}^{-1}$ under open soils. Wang et al. (2020) also observed organic carbon on higher side under protected cultivated soil as compared to open field conditions. Available nitrogen content was observed deficient but on higher side under protected soil in comparison to openly cultivated soil, with average nitrogen of $230.1 \pm 51.7$ and $199.5 \pm 45.3 \mathrm{~kg} \mathrm{ha}{ }^{-1}$ under protected/polyhouse and open/conventional soil, respectively. Chandel et al. (2017) also observed similar kind of status of available nitrogen in soils under polyhouse in North Western Himalayas.

On an average, all the fractions of nitrogen under cultivated soils under protected conditions were observed on higher side as compared to open soil and fallow soils of polyhouse and open fields. Among in-organic fraction of $\mathrm{N}_{1} \mathrm{NH}_{4}-\mathrm{N}$ varied from 10.3-28.4, 13.3-53.2, 12.4-26.8 and 12-47.6 mg kg-1 with overall mean contents of $20.6 \pm 4.6,30.9 \pm 9.4,20.3 \pm 4.1$ and $23.9 \pm 8.8 \mathrm{mg} \mathrm{kg}^{-1}$ under fallow polyhouse, protected, fallow open and openly cultivated soils, respectively (Table 2). Significant build up of $\mathrm{NH}_{4}-\mathrm{N}$ was observed both under polyhouse and open conditions in comparison to their respective fallows. Nitrate nitrogen $\left(\mathrm{NO}_{3}-\mathrm{N}\right)$ was observed significantly higher under polyhouse soil followed by open soil, fallow protected and fallow open soils with average content of $18.1,14.4,12.3$ and $11.8 \mathrm{mg}$ $\mathrm{kg}^{-1}$, respectively. Comparatively higher ammonical-N under polyhouse is understandable, as comparatively more microbial activities inside protected conditions enhanced the decomposition of organic material and mineralization/ ammonification of organic- $\mathrm{N}$, which might have contributed towards $\mathrm{NH}_{4}-\mathrm{N}$ form nitrogen in soil vis a vis comparatively more application of fertilizers and hydrolysis of nitrogenous fertilizers resulting in release of ammonium ions in soil. These results are in close conformity with the findings of Qiu et al. (2010) and Singhal et al. (2012). Also higher nitrate-N inside protected conditions as compared to conventional system might be due to lower leaching losses of $\mathrm{NO}_{3}-\mathrm{N}$. Qiu et al. (2010) also observed accumulation of $\mathrm{NO}_{3}-\mathrm{N}$ in soil under protected conditions. In organic fractions of nitrogen, similar trend was observed, where, AA-N varied from 77.2-177.2, 95-207, 81.1-124.5 and 80.7-188.1 mg kg-1 under protected fallow, cultivated polyhouse soil, open fallow and open cultivated soil, with overall mean contents of $120.4 \pm 24$, $142.7 \pm 32.2,120.9 \pm 23.5$ and $125.4 \pm 30 \mathrm{mg} \mathrm{kg}^{-1}$. Continuous addition of nitrogen through organic and inorganic sources over a long period might have contributed directly to the enrichment of this pool of organic nitrogen (Sarawad et al., 2001). Serine+threonine- $\mathrm{N}$ and hexosamine-N were observed almost similar in all land use type with no significant differences. However, higher value under protected conditions might be due to continuous addition of fertilizers for years, which might have enhanced the growth of micro-organisms resulting in the build up of this fraction in soil. Amino acid-N (AA-N) followed by hydrolysable amino acid $\left(\mathrm{HNH}_{4}-\mathrm{N}\right)$ were the most dominant contributing pool towards total hydrolysable nitrogen. Mineralization of root stubbles of vegetable crops, besides addition of nitrogen through manures may be source of hydrolysable- $\mathrm{N}\left(\mathrm{HNH}_{4}-\mathrm{N}\right)$ and amino acid-N (AA-N) resulting in the build-up of these fraction under low $\mathrm{pH}$ soils. In general, both under protected and conventional system, amino acid-N constituted about 25 and $30 \%$ of total-N and total hydrolysable-N, respectively. While, contribution of $\mathrm{HNH}_{4}-\mathrm{N}$ was observed 22 and

Table 1: Physico-chemical properties of soil

\begin{tabular}{|c|c|c|c|c|c|}
\hline Land use type & $\mathrm{pH}$ & $E C\left(d S m^{-1}\right)$ & $\mathrm{OC}\left(\mathrm{g} \mathrm{kg}^{-1}\right)$ & $\operatorname{CEC}\left(\mathrm{c} \mathrm{molP} \mathrm{P}^{+} \mathrm{ka}^{-1}\right)$ & Available N (kg ha ${ }^{-1}$ ) \\
\hline \multicolumn{6}{|l|}{ Protected } \\
\hline Mean $\pm S D$ & $5.9 \pm 0.42$ & $0.346 \pm 0.09$ & $8.1 \pm 1.2$ & $12 \pm 1.5$ & $230.1 \pm 51.7$ \\
\hline Range & $5.2-6.7$ & $0.219-0.583$ & $6.4-11.7$ & $9.4-14.4$ & $126.1-338.3$ \\
\hline \multicolumn{6}{|l|}{ Open } \\
\hline Mean $\pm S D$ & $5.6 \pm 0.33$ & $0.232 \pm 0.05$ & $7.0 \pm 0.05$ & $11 \pm 1.4$ & $199.5 \pm 45.3$ \\
\hline Range & $5.2-6.3$ & $0.131-0.338$ & $4.5-9.6$ & $8.2-13.3$ & $116.3-318.1$ \\
\hline
\end{tabular}

Values are mean of soil samples from 25 sites $\pm S D$ 
Table 2 : Status of organic and in-organic pools of $\mathrm{N}\left(\mathrm{mg} \mathrm{kg}^{-1}\right)$ in polyhouse and open cultivated soils of North-Western Himalayas

\begin{tabular}{|c|c|c|c|c|c|c|c|c|c|}
\hline \multirow{2}{*}{$\begin{array}{l}\text { Land use } \\
\text { type }\end{array}$} & \multicolumn{6}{|c|}{ In-organic fractions of nitrogen } & \multicolumn{3}{|c|}{ Organic fractions of nitrogen } \\
\hline & $\mathrm{NH}_{4}-\mathrm{N}$ & $\mathrm{NO}_{3}-\mathrm{N}$ & $\mathrm{HNH}_{4}-\mathrm{N}$ & AA-N & HA-N & ST-N & TH-N & UN & NHN \\
\hline \multicolumn{10}{|c|}{ Fallow Protected/polyhouse } \\
\hline Mean \pm SD & $20.6 \pm 4.6^{b}$ & $12.3 \pm 2.7^{b}$ & $103.7 \pm 25.5^{b}$ & $120.4 \pm 24^{b}$ & $38.4 \pm 7.9^{\mathrm{a}}$ & $34.2 \pm 8.5^{a}$ & $406.4 \pm 67.1^{b}$ & $109.7 \pm 21.9^{b}$ & $478.6 \pm 78.3^{b} 39.4 \pm 10^{b}$ \\
\hline Range & 10.3-28.4 & $7.4-16.4$ & $62.1-156.4$ & $77.2-177.2$ & $22.4-51.2$ & $20.8-55.8$ & $286-530.4$ & $68.3-169.5$ & $335.9-643.8 \quad 25.5-59.5$ \\
\hline \multicolumn{10}{|c|}{ Cultivated Protected/polyhouse soil } \\
\hline Mean \pm SD & $30.9 \pm 9.4^{a}$ & $18.1 \pm 6.8^{\mathrm{a}}$ & $125.7 \pm 28.6^{a}$ & $142.7 \pm 32.3^{\mathrm{a}}$ & $47.7 \pm 10.3^{\mathrm{a}}$ & $41.4 \pm 12.5^{\mathrm{a}}$ & $476.4 \pm 97.9^{a}$ & $118.6 \pm 21.9^{\mathrm{a}}$ & $576.9 \pm 116.4^{a} 52.1 \pm 11.1^{\mathrm{a}}$ \\
\hline Range & $13.3-53.2$ & 7.4-34.3 & $72.1-184.2$ & $95-207$ & $22.4-51.2$ & $23.3-66.1$ & $330.5-696$ & $77.6-178.5$ & $385.4-835.8 \quad 28.8-84.2$ \\
\hline \multicolumn{10}{|c|}{ Fallow Conventional/open soil } \\
\hline Mean \pm SD & $20.3 \pm 4.1^{b}$ & $11.8 \pm 2.9^{b}$ & $103.3 \pm 23.7^{b}$ & $120.9 \pm 23.5^{b}$ & $36.7 \pm 7.6^{\mathrm{a}}$ & $32.2 \pm 7.9^{\mathrm{a}}$ & $391 \pm 69.2^{b}$ & $97.9 \pm 30^{b}$ & $459.6 \pm 80.4^{\mathrm{b}} \quad 36.4 \pm 9.8^{\mathrm{ab}}$ \\
\hline Range & $12.4-26.8$ & $6.5-19.4$ & $64.1-152.3$ & $81.1-124.5$ & $21.2-49.8$ & $18.5-53.5$ & $282.4-521$ & $56.8-166$ & $338.1-623.224 .1-65.5$ \\
\hline \multicolumn{10}{|c|}{ Cultivated conventional/open soil } \\
\hline Mean $\pm S D$ & $23.9 \pm 8.8^{\mathrm{ab}}$ & $14.4 \pm 5.7^{b}$ & $114.4 \pm 27.3^{\mathrm{a}}$ & $125.4 \pm 30^{b}$ & $42.8 \pm 10.1^{\mathrm{a}}$ & $37.8 \pm 8.6^{\mathrm{a}}$ & $424 \pm 95.3^{\mathrm{ab}}$ & $106.7 \pm 30.4^{\mathrm{ab}}$ & $506.8 \pm 115.7^{b} 44.9 \pm 10.5^{b}$ \\
\hline Range & $12-47.6$ & $5.4-30.3$ & $70.4-174.2$ & $80.7-188.1$ & $25.2-64.1$ & $24.8-61.6$ & $272.2-660.9$ & $63.2-173$ & $339.3-800.7 \quad 31.8-73.7$ \\
\hline
\end{tabular}

Values are mean of soil samples from 25 sites $\pm S D$; Values with same letter in same column are not significantly different at $p \leq 0.05 ; \mathrm{HNH}_{4}-\mathrm{N}$ : Hydrolysable ammonical-N, AA-N: amino acid-N, ST-N: serine + threonine-N, HA-N: Hexosamine-N, UN: Unidentified-N, NH-N: non hydrolysable-N, TH-N: total hydrolysable-N and TN: Total-N.

Table 3 : Correlation coefficients $(r)$ of different nitrogen fractions with soil properties under protected and conventional cultivation

\begin{tabular}{|c|c|c|c|c|c|c|c|c|}
\hline \multirow{2}{*}{$\begin{array}{l}\text { Fraction of } \\
\text { nitrogen }\end{array}$} & \multicolumn{4}{|c|}{ Protected/Polyhouse properties } & \multicolumn{4}{|c|}{ Conventional/open soil } \\
\hline & $\mathrm{pH}$ & $\mathrm{OC}$ & CEC & Available N & $\mathrm{pH}$ & $\mathrm{OC}$ & CEC & Available N \\
\hline $\mathrm{NH}_{4}-\mathrm{N}$ & 0.140 & $0.840^{* *}$ & $0.742^{* *}$ & $0.851^{* *}$ & 0.210 & $0.814^{* *}$ & $0.571^{* *}$ & $0.615^{* *}$ \\
\hline $\mathrm{NO}_{3}^{4}-\mathrm{N}$ & 0.180 & $0.696^{* *}$ & $0.647^{* *}$ & $0.838^{* *}$ & 0.290 & $0.633^{* *}$ & $0.570^{* *}$ & $0.564^{* *}$ \\
\hline $\mathrm{HNH}_{4}-\mathrm{N}$ & 0.309 & $0.776^{* *}$ & $0.743^{* *}$ & $0.923^{* *}$ & 0.188 & $0.728^{* *}$ & $0.626^{* *}$ & $0.868^{* *}$ \\
\hline HA-N & 0.376 & $0.709^{* *}$ & $0.684^{* *}$ & $0.796^{* *}$ & 0.164 & $0.603^{* *}$ & $0.652^{* *}$ & $0.796^{* *}$ \\
\hline AA-N & 0.311 & $0.688^{* *}$ & $0.688^{* *}$ & $0.898^{* *}$ & 0.282 & $0.685^{\star *}$ & $0.573^{* *}$ & $0.849^{* *}$ \\
\hline ST-N & 0.283 & $0.718^{* *}$ & $0.659^{* *}$ & $0.835^{\star *}$ & 0.281 & $0.681^{* *}$ & $0.541^{* *}$ & $0.830^{* *}$ \\
\hline UN & 0.256 & $0.640^{\star *}$ & $0.672^{* *}$ & $0.677^{\star *}$ & 0.252 & $0.498^{* *}$ & 0.337 & $0.730^{* *}$ \\
\hline $\mathrm{NHN}$ & 0.309 & $0.568^{\star *}$ & 0.332 & $0.411^{*}$ & 0.104 & $0.640^{* *}$ & $0.541^{* *}$ & $0.562^{* *}$ \\
\hline
\end{tabular}

*Significant at $5 \%$ level, ${ }^{* *}$ Significant at $1 \%$ level; $\mathrm{HNH}_{4}-\mathrm{N}$ : Hydrolysable ammonical-N, AA-N: amino acid-N, ST-N: serine + threonine-N, HA-N: Hexosamine-N, UN: Unidentified-N, NH-N: non hydrolysable-N.

$26 \%$ towards TN and TH-N. Unidentified-N fraction of soil was calculated by subtracting hydrolysable ammonical-N, amino acid$\mathrm{N}$, hexosamine- $\mathrm{N}$ and serine + threonine- $\mathrm{N}$ from total hydrolysable- $\mathrm{N}$, therefore varies with the contents of all the organic pools of nitrogen. Similarly, non hydrolysable-N (NH-N) also determined subtracting total hydrolysable-N and inorganic- $\mathrm{N}$ fractions from total $\mathrm{N}$ in soil. Total hydrolysable- $\mathrm{N}$ is the portion of total nitrogen which is hydrolysable in nature. Fallow soils both under protected and open environment were observed with low contents of TN and THN, which might be due to lack of external addition of manures and fertilizers and mineralization of existing organic matter reserve. The results are in conformity with the findings of Shilpashree et al. (2012).

As available nitrogen are derived from organic and inorganic chemical pools of nitrogen, all the organic and inorganic fractions of nitrogen were observed in a complete correlation with available nitrogen and other chemical properties of soil both under conventional and protected system of cultivation, except soil pH (Table 3). Available form of nitrogen in protected system of cultivation was observed highly correlated with hydrolysable ammonical-N, with correlation coefficient $(r)$ value of 0.923 under polyhouse soil followed by amino acid-N ( $r=0.898)$, while CEC was found to be highly cor-related with hydrolysable ammonical$\mathrm{N}$, followed by ammonical-N with correlation coefficient ( $\mathrm{r}$ ) value of 0.743 and 0.742 , respectively. Under open cultivated soils, the relation of nitrogen fractions with soil reaction was nonsignificant. However, available form of nitrogen followed almost similar trend and highest correlation was observed with $\mathrm{HNH}_{4}-\mathrm{N}$ ( $r=0.868)$, followed by AA-N ( $r=0.848)$. Durani at al. 2016 also observed that out of the total nitrogen maximum was transformed to amino acid- $\mathrm{N}(23 \%)$, followed by hydrolysable $\mathrm{NH}_{4}-\mathrm{N}(22 \%)$. 
These results are in conformity with Shabnam et al. (2017). Amino acid-N and Hydrolysable-N are the major contributing organic fractions towards total $\mathrm{N}$ and highly correlated with available $\mathrm{N}$.

The results suggested that overall mean of all the fractions of organic as well as inorganic fractions of nitrogen showed a slight build up in comparison to nitrogen fractions in fallow soil, both under protected and open field conditions. All the pools were observed to be affected with the management practices. In addition, further investigation revealed that the nutrient release under protected environment in comparison to open filed are necessary to observe the changes and adverse effect with ages of cultivation under polyhouse conditions.

\section{Acknowledgment}

Authors would like to thank Dr. R.S. Rana, Centre of GeoInformatics, CSKHPKV, Palampur.

\section{References}

Benbi, D.K. and G.S. Saroa.: Soil health and agriculture sustainability in Punjab. In: $77^{\text {th }}$ Ann. Conven. Indian Soc. Soil Sci, Dept. of Soil Sci., PAU, Ludhiana (2012).

Black, C.A.: Methods of Soil Analysis. Part II. American Soc. Agron., Madison, Wisconsin, USA(1965).

Bremner, J.M.: Methods of Soil Analysis. Part II (Ed.: C.A. Black) American Soc. Agron., Madison, Wisconsin, USA (1965).

Chandel, S., D. Tripathi and R. Kakar.: Soil health assessment under protected cultivation of vegetable crops in North-West Himalayas. J. Environ. Biol., 38, 97-103 (2017).

Chaudhary, A.K.: Scaling-up of protected cultivation in Himachal Pradesh, India. Curr. Sci., 111, 272-277 (2016).

Durani A., B.S. Brar and G.S.Dheri: Soil nitrogen fractions in relation to rice-wheat productivity: Effects of long term application of mineral fertilizers and organic manures. J. Crop Improv., 30, 399-420 (2016).

Fageria, N.K. and V.C. Baligar: Nutrient Availability. In: Encyclopedia of Soils in the Environment (Edf.: D. Hillel). Elsevier, pp. 63-71 (2005).

Jackson, M.L.: Soil Chemical Analysis. Prentice Hall Inc. Englewood Cliffs, New Jersey, USA(1973).

Kokate, K.D., A.M. Narula, S.K. Thakur, P. Sood and D.S. Yadav.:
Protective cultivation: KVKs initiative in Himachal Pradesh. Zonal Project Directorate, Zone-1, Indian Council of Agricultural Research, PAU Campus, Ludhiana, pp. 77 (2012).

NHB: Area and Production estimates for the year 2016-17. http://nhb.gov.in/Statistics.aspx?enc=WkegdyuHokljEtehnJogOK WLU79sOQCy+W4MfOk01GFOWQSEvtp9tNHHoiv3p49g. (2016-17).

Piper, C.S.: Soil and Plant Analysis. Asian Edn., Hans Publisher, Bombay, pp. 223-237 (1966).

Qiu, S.J, X.T. Ju, J. Ingwersen, Z.C. Qin, L. Li, T. Streck, P. Christie and F.S. Zhang: Changes in soil carbon and nitrogen pools after shifting from conventional cereal to greenhouse vegetable production. Soil Tillage Res., 107, 80-87 (2010).

Reynolds, W.D., C.F. Drury, C.S. Tan , C.A. Fox and X.M. Yang: Use of indicators and pore volume function characteristics to quantify soil physical quality. Geoderma, 152, 252-263 (2009).

Sarawad, L.M., D. Singh, D.S. Rana and K. Kumar.: Nitrogen fractions and their relationships with mineralizable nitrogen and its uptake by crops in a long-term fertilizer experiment. J. Indian Soc. Soil Sci., 49, 691-694 (2001).

Shabnam, S.K. Sharma, R.S. Rana and N.K. Sankhyan: Long-term effect of prescription based nutrient application on forms of nitrogen in relation to soil chemical properties, yield and nutrients uptake in an acid Alfisol of North-Western Himalayas. The Ecoscan, 11, 1-6 (2017).

Shilpashree, V.M., H.M. Chidanandappa, R. Jayprakash and B.C. Punitha: Effect of integrated nutrient management practice on distribution of nitrogen fractions by maize crop in soil. Indian $\mathrm{J}$. Fund. App. Life Sci., 2, 38-44 (2012).

Singhal, S.K., R.D. Singh, V.K. Sharma and S.K. Sharma: Impact of integrated use of fertilizer and enriched compost on yield, nitrogen uptake by wheat and frations of soil nitrogen in semi arid condition. Indian J. Agri. Res., 46, 262-268 (2012).

Steel, R.G.D. and J.H. Torrie: Principles and Procedures of Statistics. New York: McGraw-Hill Book Company (1960).

Subbiah, B.V. and G.L. Asija: A rapid procedure for the determination of available nitrogen in soils. Curr. Sci., 25, 259-260 (1956).

Walkley, A. and I.A. Black: An examination of the Degtjareff (wet acid) method for determining soil organic matter and a proposed modification of the chromic acid titration method. Soil Sci., 37, 2938 (1934).

Wang, Z., G. Dianqing and Y. Zhang: Investigating the effects of greenhouse vegetable cultivation on soil fertility in Lhasa, Tibetan Plateau. Chinese Geo. Sci., 30, 456-465 (2020). 